\title{
Geomorphological processes and frozen ground conditions in Elephant Point (Livingston Island, South Shetland Islands, Antarctica)
}

\author{
Marc Oliva ${ }^{\mathrm{a}, *}$, Jesús Ruiz-Fernández ${ }^{\mathrm{b}}$ \\ a Centre for Geographical Studies - IGOT, Universidade de Lisboa, Rua Branca Edmée Marques, 1600-276, Lisbon, Portugal \\ b Department of Geography, University of Oviedo, Teniente Alfonso Martínez s/n, 33011 Oviedo, Spain
}

\section{A R T I C L E I N F O}

\section{Article history:}

Received 2 January 2015

Received in revised form 19 January 2016

Accepted 31 January 2016

Available online 3 February 2016

\section{Keywords:}

Elephant Point

Maritime Antarctica

Geomorphology

Frozen ground

Permafrost

\begin{abstract}
A B S T R A C T
Elephant Point is an ice-free area in the SW corner of Livingston Island (Maritime Antarctica). The retreat of Rotch Dome glacier during the Holocene has exposed a land area of $1.16 \mathrm{~km}^{2}$. Up to $17.3 \%$ of this surface has become ice-free between 1956 and 2010. A detailed geomorphological mapping of this ice-free environment was conducted in late January 2014. A wide range of active periglacial landforms show that periglacial processes are widespread. From the glacier to the coast four different geomorphological areas are identified: proglacial environment, moraine complex, bedrock plateaus and marine terraces. In situ measurements of the thawed soil depth show evidence of the widespread frozen ground conditions in the area. Field observations of permafrost exposures suggest that these frost conditions may be related to a soil permafrost regime, almost down to sea level. The activity of penguin colonies and elephant seals has created minor geomorphological features in the raised marine terraces. Here, several archaeological sites related to early human colonization of Antarctica were also found in natural shelters.
\end{abstract}

(C) 2016 Elsevier B.V. All rights reserved.

\section{Introduction}

Only $0.4 \%$ of the Antarctic surface is ice-free terrain (Cary et al., 2010). The ice-free environments correspond to: (a) nunataks standing out of the glacial ice, (b) dry areas in the interior of the continent conditioned by the topography (e.g. Dry Valleys), and (c) coastal enclaves especially along the Antarctic Peninsula (AP) region, where mean annual temperatures are close to $0{ }^{\circ} \mathrm{C}$ and glacier retreat has exposed the land surface. It is one of these ice-free areas, Elephant Point (Livingston Island, South Shetland Islands), where this paper focuses.

The deglaciation process of the coastal ice-free areas in the AP started after the Last Glacial Maximum (Ingólfsson et al., 1998, 2003; Seong et al., 2009; Balco et al., 2013). This long-term pattern towards less glacial ice continued thorough the Early and Mid Holocene when warmer climate conditions prevailed in the western AP region as inferred from ice cores (Bentley et al., 2009) and marine sediments (Bentley et al., 2011; Shevenell et al., 2011). The timing and magnitude of Holocene climate oscillations are significantly different in the West and East of the AP (Bentley et al., 2009). Our study area is located in the western AP, where conditions are warmer than in the eastern part and summer temperatures closer to $0{ }^{\circ} \mathrm{C}$, thus the impact of warmer conditions in the terrestrial ecosystems is larger. In fact, Holocene climate variability has resulted in significant palaeoenvironmental and

\footnotetext{
* Corresponding author at: Centro de Estudos Geográficos/IGOT, Universidade de Lisboa, Edifício FLUL, Alameda da Universidade, 1600-214 Lisboa, Portugal.

E-mail address: oliva_marc@yahoo.com (M. Oliva).
}

palaeoecological changes in ice-free areas in Maritime Antarctica, namely in the distribution of coastal fauna (Sun et al., 2000; del Valle et al., 2002), glacio-isostatic uplift and formation of raised beaches (Fretwell et al., 2010), variations on the pattern of the sedimentological processes prevailing in lakes (Toro et al., 2013) as well as advances and retreats of glaciers (Hall et al., 2010). In this sense, in Livingston island, fluctuations of the Rotch Dome glacier during the Holocene glacier are confirmed by lake records from the nearby Byers Peninsula (Björck et al., 1991, 1996).

During the Late Holocene colder and warmer periods alternated until the second half of the past century, when an accelerated warming trend has been recorded in the entire AP region (Mulvaney et al., 2012; Abram et al., 2013; Steig et al., 2013). In fact, the warming rate in the AP has been quantified in the order of $0.5^{\circ} \mathrm{C} /$ decade, one of the largest temperature increases on Earth (Turner et al., 2005; Steig et al., 2009). These climate conditions have led to an acceleration of snow melt and glacier mass loss in the AP region (Rückamp et al., 2011; Abram et al., 2013). For the South Shetland Islands (SSI), the retreat between 1956 and 2000 involved loss of $4.5 \%$ of the total ice volume of $1076 \pm 0.055 \mathrm{~km}^{3}$ that existed in 1956 (Molina et al., 2007). In Livingston the glacierized area has decreased from $734 \mathrm{~km}^{2}$ in 1956 to $703 \mathrm{~km}^{2}$ in 1996 (Calvet et al., 1999) and $697 \mathrm{~km}^{2}$ in 2004 (Osmanoglu et al., 2013); an approximately decline of $0.8 \mathrm{~km}^{2}$ of the total glacier surface per year. However, a deceleration of the mass losses has been detected between 2002 and 2011 in this island (Navarro et al., 2013).

These shifts in mass balance have implications for the extent of the ice-free areas, which have significantly expanded over the last decades. 
With the gradual displacement of the Equilibrium Line Altitudes to higher elevations in the SSI, the margins of these islands mostly covered by ice-caps have become ice-free. The terrestrial ecosystem in the icefree areas in Livingston Island, and in general in all the SSI, is strongly conditioned by the lack of permafrost in coastal environments up to $20 \mathrm{~m}$ a.s.l., discontinuous permafrost at altitudes between 20 and $40 \mathrm{~m}$ a.s.l., turning to continuous permafrost at higher elevations (Serrano et al., 2008; Ramos et al., 2009; Vieira et al., 2010; Bockheim et al., 2013). In all elevation belts periglacial landforms are widespread and periglacial processes are very active. The spatial distribution of these landforms in the ice-free areas in the islands surrounding the north of the AP is well-known, since most of these areas have been subjected to geomorphological mapping (López-Martínez et al., 1996, 2012; Serrano and López-Martínez, 1997; López-Martínez and Serrano, 2002; Guglielmin et al., 2008).

Byers Peninsula, located in the westernmost part of Livingston, is the largest ice-free area in the SSI and includes the largest biodiversity in Maritime Antarctica (Toro et al., 2007). A wide range of multidisciplinary studies has been conducted in this area over the last decade (Quesada et al., 2013). However, this knowledge is strictly limited to Byers Peninsula, and does not extend to neighbouring areas, such as the focus of this research, Elephant Point.

In general, in Antarctica the areas with little information about the dynamics of the terrestrial ecosystem are those distributed in areas where access and logistics are particularly difficult. This is also the case of Elephant Point, from where geomorphological knowledge in the scientific literature is inexistent. A field reconnaissance survey was conducted in January 2014 with the purpose of filling this gap. The specific objectives of this paper are to:

- Introduce a high-resolution geomorphological map and an accurate description of the geomorphological features distributed in this icefree area.

- Discuss the present-day distribution and characteristics of the frozen ground conditions.

- Interpret the palaeoenvironmental evolution in Elephant Point based on geomorphological and sedimentological evidences.

\section{Study area}

Elephant Point constitutes a small ice-free area in the SW fringe of Livingston, an island covered nowadays by glacier ice over approximately $84 \%\left(\sim 690 \mathrm{~km}^{2}\right)$ of its surface $\left(818 \mathrm{~km}^{2}\right)$. The retreat of Rotch Dome glacier has generated several ice-free areas in the western margins of Livingston, such as Byers Peninsula, located only $3 \mathrm{~km}$ west from Elephant Point (Fig. 1). At present-day, the deglaciated area in Elephant Point comprises a surface of only $1.16 \mathrm{~km}^{2}$.

Climate conditions in the western half of Livingston are characterized by colder temperatures and windier conditions than in the other islands of the SSI (Bañón et al., 2013). At the nearby Byers Peninsula the annual average temperature for the period 2002-2010 was $-2.8{ }^{\circ} \mathrm{C}$ at $70 \mathrm{~m}$ a.s.l. (Bañón et al., 2013). Annual precipitation in these islands is relatively high, ranging from 500 to $800 \mathrm{~mm}$. The

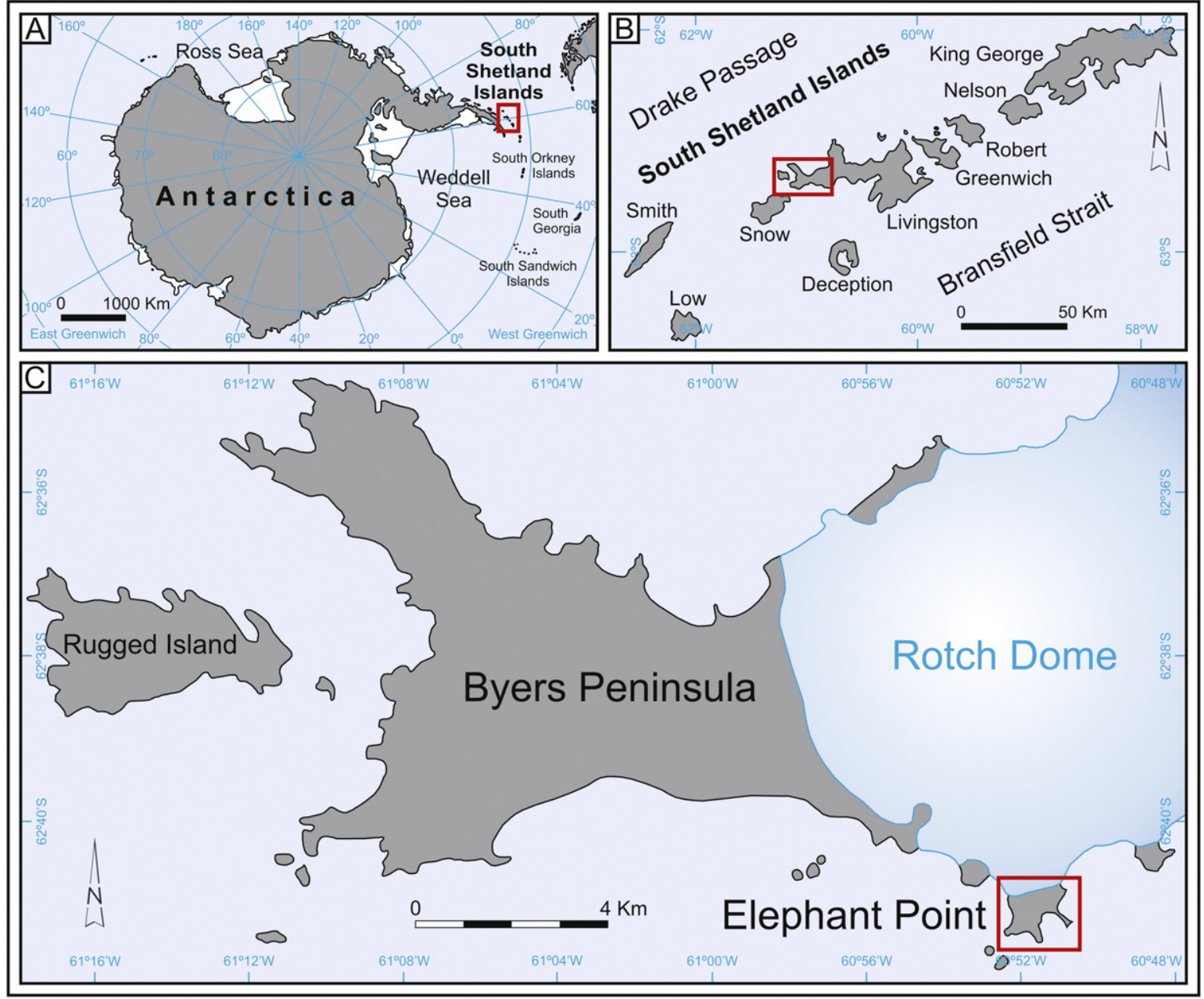

Fig. 1. Location of Elephant Point in Livingston Island. 
highest accumulation is concentrated in the summer season, both in the form of rain or snow.

The lithology of Elephant Point is dominantly composed of heavily weathered basalts. Evidence of other lithologies such as granodiorites and shales have been only identified in the morainic sediments. As in the other ice-free environments in the SSI, in this peninsula the terrestrial ecosystem is strongly controlled by the distribution of permafrost and by active layer dynamics. Periglacial processes are very active down to the coastline. The vegetation cover is very sparse, mostly constituted by mosses and lichens. Dense moss beds are also found in environments with abundant wildlife, namely in areas with bird colonies. The only two native vascular plants living in Antarctica - Deschampsia Antarctica and Colobanthus quitensis, Vera (2011) - only appear in the flat marine terraces next to the coast and where they are protected from the wind.

\section{Materials and methods}

Geomorphological mapping of Elephant Point was conducted in the field based on the satellite image of Google Earth from 2010. The field work campaign took place in late January 2014, when snow had already melted from most of this peninsula. The geomorphological map was generated using the RCP 77 mapping system (Joly, 1997).

The comparison of the aerial image of 1956 (U.S. Geological Survey) with the recent image of 2010 has allowed to infer the area deglaciated over the last decades.

The thickness of the thawed layer at the end of January 2014 was also measured with a 1 -m long metal probe in 49 sites along three transects covering the entire peninsula, from the coast to the present-day glacier front (Fig. 1). It should be taken into account that the winter and spring seasons of 2013 were much snowier and colder than usual in the SSI, which conditioned a delay of the snow melting period, thus, affecting the timing and thickness of the soil thawing.

\section{Results}

\subsection{Geomorphological setting}

The Rotch Dome is a small ice cap limiting the northern border of the ice-free area of Elephant Point. The coastline constitutes the western and eastern limits of this peninsula. The dome morphology of the ice conditions a gentle slope in the contact between the glacier and the ice-free area. By contrast, the contact between the glacier and the sea generates steep ice fronts. In the glacier front several tephra layers are distinguished, as observed in other sites on Livingston island (Pallàs et al., 2001).

Apart from the glacial area, up to four main different geomorphological units are identified in the ice-free area in Elephant Point (Fig. 2):

\subsubsection{Proglacial area}

The northward retreat of the Rotch Dome glacier over the last decades has exposed the land surface between the innermost moraine ridge and the present-day glacier front. Comparison of the aerial image of 1956 and the satellite image of 2010 suggests an approximate surface retreat of $0.202 \mathrm{~km}^{2}$ for this period, which accounts for about 17.3\% of the ice-free surface today in Elephant Point (Fig. 3).

In the central part of this proglacial area there is a relative flat plateau at an elevation of $20 \mathrm{~m}$ a.s.l. constituted by the bedrock surface (schists) and loose glacial debris distributed on it. Here, incipient centimetric stone sorted-circles and stone stripes are forming. Formerly, this plateau used to be an area with divergence of glacial flow (WestEast). Since its deglaciation, the drainage system flows eastwards and westwards from this plateau towards the coast, flowing between the present-day glacier front and the moraine. Fluvioglacial processes are eroding the unconsolidated glacial sediments.
In the western part of this proglacial area at elevations of 5-10 $\mathrm{m}$ a.s.l. the relief is relatively flat and concentrates tens of kettle-lakes as well as a small lagoon near the coast fed by glacier-melting waters. In the eastern half a $3-5 \mathrm{~m}$ high moraine is being cut by the surface runoff. Several aligned longitudinal debris ridges (0.6-1 m height) are distributed along the margin of the glacier. Their surface is constituted by finegrained sediments while their internal structure is composed of a core of glacial ice. This minor moraine ridges correspond to squeeze moraines and are formed by the squeezing of saturated sediments from beneath ice cap margins (Evans, 2007; Benn and Evans, 2010). The stream draining eastwards forms an alluvial fan near the coast.

\subsubsection{Moraine system}

This geomorphological unit stretches from the western to the eastern edges of the peninsula with a ridge height ranging from 25 to $55 \mathrm{~m}$. On the western side it descends smoothly to the present-day shoreline, whilst on the eastern flank the moraine sits directly on the underlying bedrock, falling vertically to the beach. The external and internal moraine ridges constitute the highest elevations of this peninsula (50-55 m a.s.l.), with a series of arcuate ridges and furrows in between. Some of these depressions are filled with water from the snow melting and thawing of the active layer, which generates small semi-permanent lagoons.

The lithological composition of the moraine sediments differs substantially from the homogeneous basalt bedrock present in this peninsula. Though basalt clasts are the most abundant, granodiorites and shales are also identified (Fig. 4a). Frost shattering is very intense across the moraine area. The size of the highly weathered rocks is usually small ( $\leq 30 \mathrm{~cm}$ of long axis), though blocks up to $1 \mathrm{~m}$ diameter have been observed in the ridge of the internal moraine (basically granodiorites and basalts). Some of these blocks exhibit evidence of glacial abrasion, namely polished surfaces and glacial striae. In flat areas of the upper part of the moraine sediments are being intensively reworked by cryoturbation processes, generating stone sorted-circles and stone stripes of centimetric size.

In the outermost edge of the moraine many boulders show a rounded morphology. This is observed only in the most resistant boulders (basalts and granodiorites), whereas the blocks of other lithologies are angular to subangular and heavily weathered.

Bones of whale (ribs) were found in two sites of the most external moraine at 42 and $44 \mathrm{~m}$ a.s.l., respectively. In one site several pieces of ribs were found spread in the surface, whereas the other rib appeared completely preserved $(1.1 \mathrm{~m}$ long) embedded in the moraine. In contrast to the recent whale bones found near the present-day beach where its core shows a pale colour, in these two bone samples it was dark and looked highly weathered (Fig. 4b).

The dissymmetry of the moraine slopes promotes different geomorphological processes at both sides. While the north exposed slope declines gently to the glacier $\left(22^{\circ}\right)$, the southern side falls steeply to the principal bay of Elephant Point $\left(35^{\circ}\right)$. In the northern slope the higher insolation explains the absence of snow at late January, which leads to a deeper and faster thawing of the active layer. The consequence of this fact is seen in the widespread slow (solifluction) and fast (mudflows) periglacial mass movements reworking the unconsolidated moraine sediments in the northern slope. Fragments of the shattered rocks in the moraine are being mobilized downvalleys by solifluction processes. Mudflows are generated at the contact between the permafrost and the active layer. The permafrost table acts as the sliding surface for the mobilization downslope of the water-saturated overlying sediments (Video 1). The accumulation of these sediments forms alluvial fans in the contact with the glacier front. Some frost mounds (1-1.5 m height) are also identified on this slope (Fig. 5a).

Slope processes are less widespread at the southern side of the moraine, where large and long-lying snow patches persist until midsummer in sheltered locations. The sliding of the unconsolidated glacial debris downslope over these snow-patches accumulates the sediments 


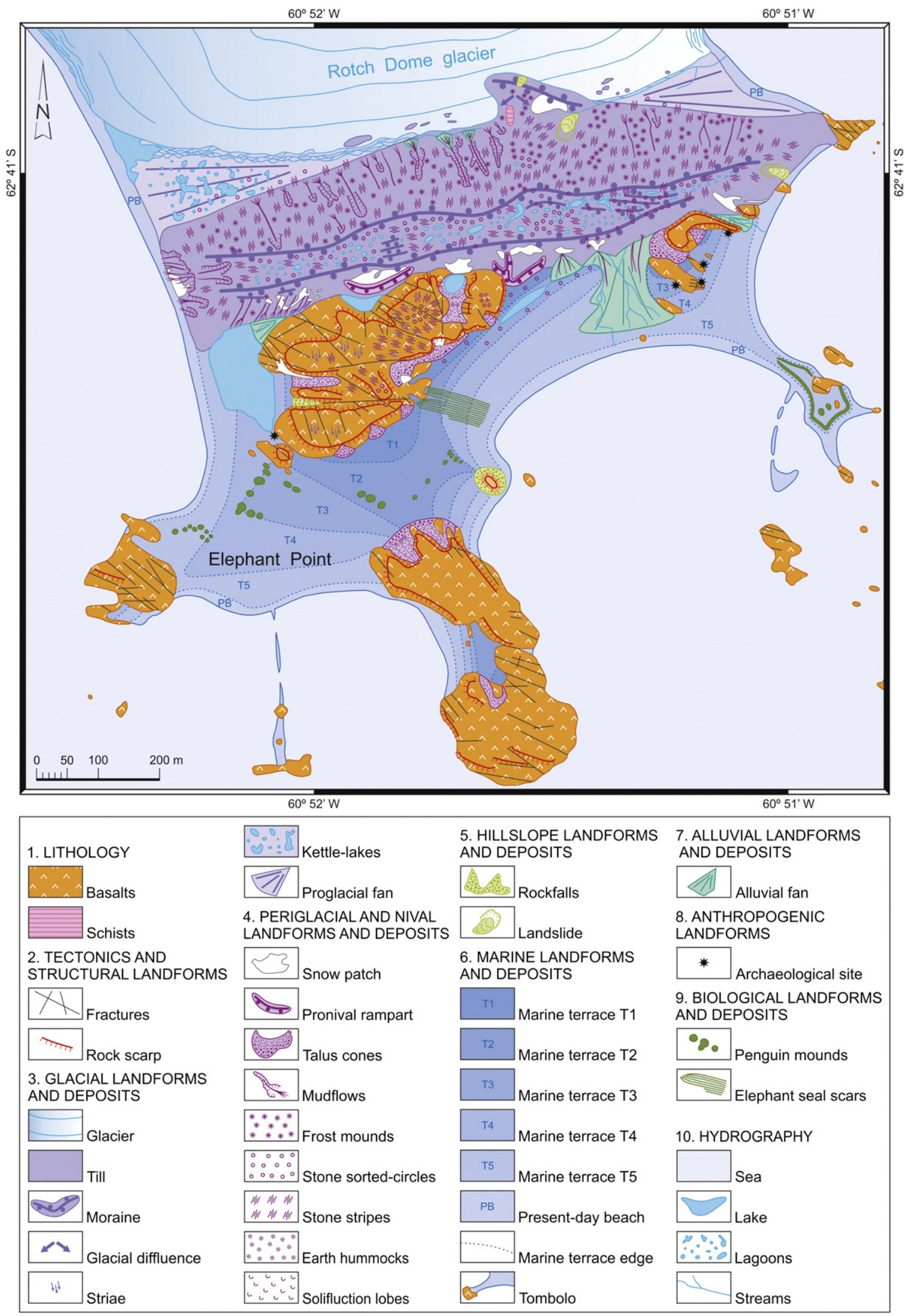

Fig. 2. Geomorphological map of Elephant Point.

at their foot, generating three pronival ramparts of $1.5-2 \mathrm{~m}$ height and $50-100 \mathrm{~m}$ length. The arcuate ridge of the pronival ramparts is steep and composed of large boulders (Fig. 5b), while a basal talus comprising clasts and fine-grained particles accumulated downslope.
Closed by the moraine and the surrounding plateaus there is an endorheic lake, which experiences significant variations of water level. According to visual observations of the wet margins of the lake, a diminution of ca. $3 \mathrm{~m}$ must have occurred little before our field work 
A
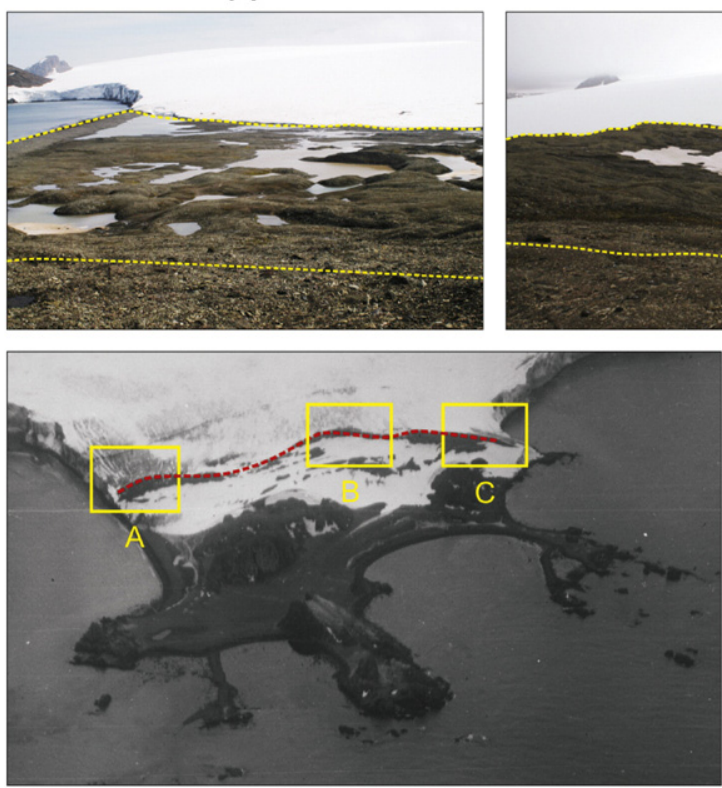

B

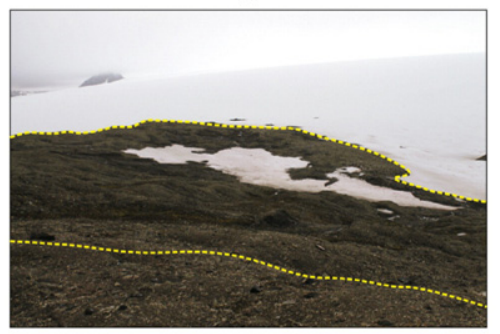

C

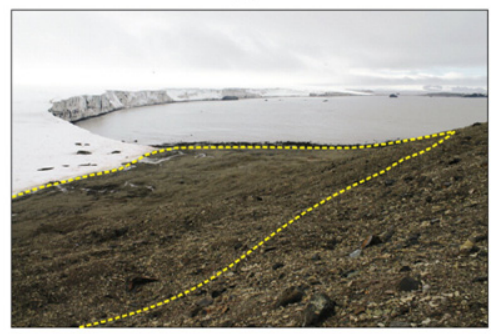

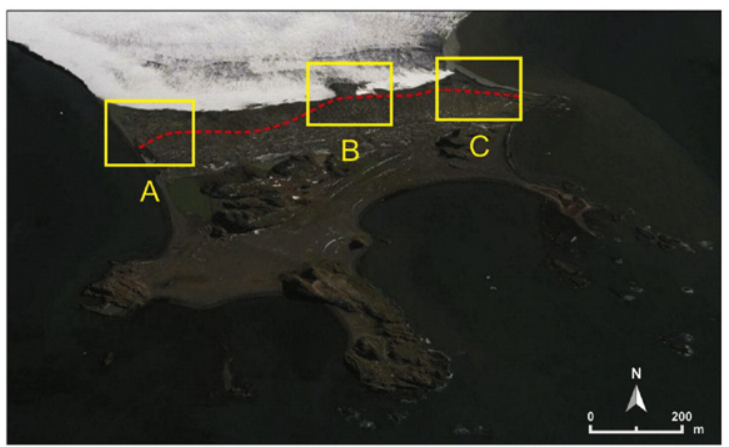

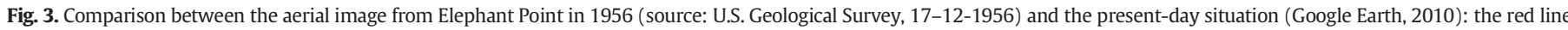
indicates the position of the internal moraine in 1956 (figure below), and the yellow lines show the deglaciated terrain since 1956 (figure above).

campaign in the area. In contact with these pronival ramparts at the East there is an alluvial fan fed by several debris flows triggered by the melting of a snow-patch (Table 1).

\subsubsection{Bedrock plateaus}

These flat surfaces reach elevations of $40-50 \mathrm{~m}$ a.s.l. They are constituted by basalt outcrops showing columnar jointing. This geometrical pattern of thin fractures is especially visible at the SE of the westernmost coastal lagoon. These outcrop surfaces are structured by a network of fractures following two main directions: NWSE (principal) and E-W (secondary). Rockfall activity is intense in these outcrops and several well-developed sorted talus cones are distributed at the foot of these cliffs.

In these plateaus there are some areas intensely used by birdlife, which has generated ornithogenic soils. These very organic-rich soils can reach a thickness of $30-40 \mathrm{~cm}$, favouring the development of a dense vegetation cover of mosses, lichens and gramineous grasses on them. Earth hummocks and vegetated solifluction landforms are distributed in these densely vegetated areas.
By contrast, in vegetation-free areas with fine-grained sediments and gentle slopes $\left(6-12^{\circ}\right)$ sorted-circles and stone stripes are widespread (Fig. $\mathrm{c}$ and d). In rocky surfaces, some of the blocks are slightly polished and exhibit traces of glacial striae running $\mathrm{N}-\mathrm{S}$.

\subsubsection{Marine terraces and present-day beach}

A series of relatively flat surfaces at elevations between 2 and $10 \mathrm{~m}$ a.s.l. are distributed near the coastline (Table 2). The presence of rounded cobbles at the surface suggests that these flat platforms correspond to five different levels of marine terraces.

The fronts of the terraces are constituted by coarser sediments, while the flat areas are covered with fine-grained sediments. The horizontal topography favours the storage of meltwater in semi-permanent elongated lagoons on terraces T2 and T3. In the westernmost fringe of Elephant Point, there is a lagoon lying on T4 - constrained by the moraine and two alluvial fans - that constitutes the largest freshwater body in this peninsula. Terraces $\mathrm{T} 1$ to $\mathrm{T} 3$ are composed of coarser sediments than T4 and T5. There are also significant differences in terms of height and spatial extension of these terraces: while T1, T2 and T3 are
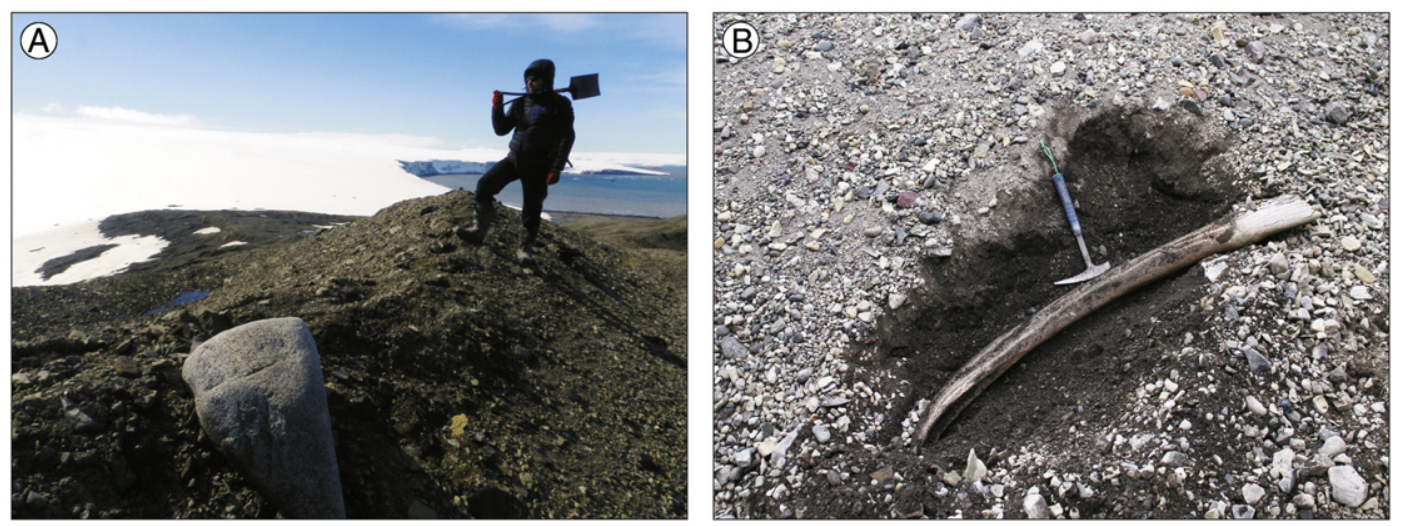

Fig. 4. Granodiorite boulder in the internal moraine ridge (a), and whale bone inserted in the outer arc of the moraine (b) 

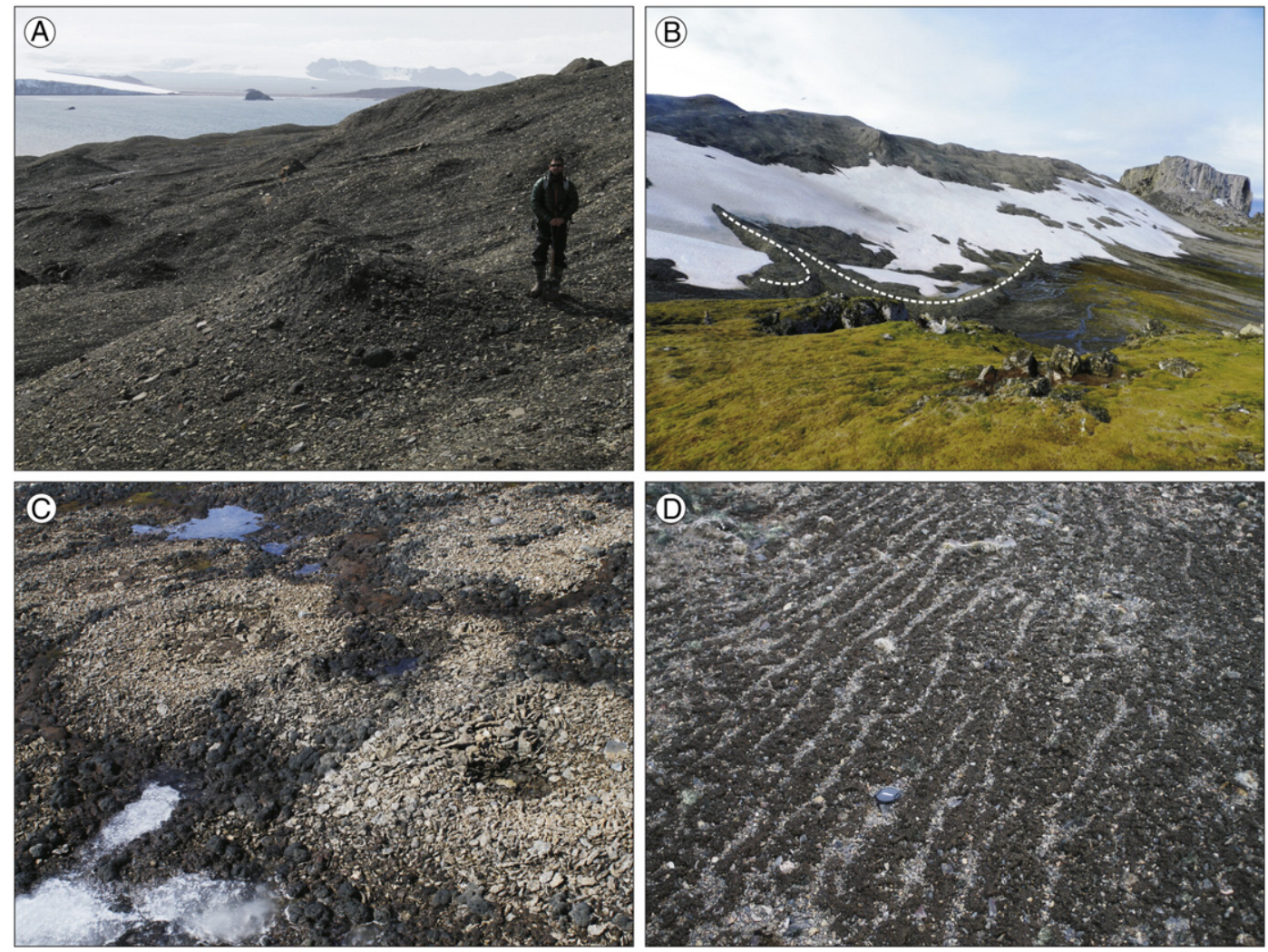

Fig. 5. Main periglacial landforms observed in Elephant Point: frost mounds (a), pronival ramparts (b), sorted-circles (c), and stone stripes (d).

geographically limited and separated by a higher elevation difference, T4 and T5 occupy a vast area in a relatively flat environment. T5 connects gently with the current storm beach. In the eastern third of the main bay the marine terraces have been overlain by an active alluvial fan built up by water flow derived from snow melt and debris flows generated in the moraine.

Periglacial activity is also intense in the terraces, namely through cryoturbation processes. Patterned ground landforms occur in T1, T2 and T3. In T3 mudboils are very abundant and boulders (up to $20 \mathrm{~cm}$ of diameter) are being ejected to the surface. Pipkrakes are also observed in all terraces, especially in areas with high water supply. They are more common everywhere after snow or rain events.

There is a close relationship between some geomorphological landforms and biological activity in these terraces. There is a colony of elephant seals in the uppermost terrace T1. In order to reach this colony these animals must pass through the lower terraces, and by hauling they produce aligned and parallel scars perpendicular to the terraces. Erosion is very intense especially in the ramp from T3 to T2 and from T2 to T1 (Fig. 6a). On the other hand, in the margins of the scars as well as on the flat platforms of the terraces T1 and T2 a dense vegetation cover is present due to the existence of organicrich soils originated from seal excrement. Furthermore, several active and abandoned penguin rookeries are distributed in terraces T2-T5 and T5 in the western part of the peninsula, where the long-term guano inputs have generated mounds up to $1 \mathrm{~m}$ high and $5 \mathrm{~m}$ long (Fig. 6b).

It is noteworthy to mention the existence of a tombolo in the SE tip of the peninsula, generated on the most recent marine terrace. It is occupied by a penguin rookery. Another tombolo is being built up in connection with an offshore rock only exposed during low tides. The same process is detected in the westernmost bay (Fig. 2).

In the SE corner of Elephant Point, next to rocky outcrops in marine terraces T3 and T4, there are also some metre-sized features which are not related to a natural landscape formation. The existence of several rectangular-shaped buildings of wall stones shows evidence of an early human occupation in the area.

\subsection{Frozen ground measurements}

Data about the depth of the thawed layer are based on discrete measurements conducted in late January 2014, after a cold and snowy winter and spring in the SSI. Therefore, these conditions delayed the snow melting period and conditioned the timing and depth of soil thawing.

The measurements along the three transects reported an average depth of $57.5 \mathrm{~cm}$ from the surface (Table 3). The deepest layers corresponded to the moraine ridges and near the shoreline. In two sites on the lowest marine terraces no frozen layer was found at $1 \mathrm{~m}$ depth. The shallowest depths $(25-30 \mathrm{~cm})$ were always measured adjacent to late-lying snow patches, in areas that became snow-free shortly before our field measurements. The transects crossed several geomorphological landforms from the glacier to the coastline, showing evidence of the large variability of the thaw depth observed in this peninsula for a specific time period (Fig. 7).

There is visible evidence suggesting that most of the measurements of the frozen ground conditions are related to the presence of permafrost. In the scars created by mudflow activity permafrost is exposed at the surface (Fig. 8). In-situ observations of these exposures revealed that the moraine is constituted by ice-rich permafrost, enclosing abundant subangular clasts in a sandy matrix. Permafrost associated with mudflows was observed almost down to sea level, at elevations of 3-5 m.

\section{Discussion}

\subsection{Past environmental dynamics in elephant point}

Elephant Point is an ice-free environment in Livingston Island generated by the retreat of Rotch Dome. The generalized glacier retreat in the 
Table 1

Geomorphological landforms identified in Elephant Point.

\begin{tabular}{|c|c|c|}
\hline $\begin{array}{l}\text { Geomorphological } \\
\text { unit }\end{array}$ & Landforms & Characteristics, distribution and dimensions \\
\hline \multirow[t]{5}{*}{ Proglacial area } & Stone sorted-circles & Features of centimetre size developed in gentle areas $\left(4-6^{\circ}\right)$ with fine-grained sediments. \\
\hline & Stone stripes & Features of centimetre size developed in gentle slopes $\left(8-12^{\circ}\right)$ with fine-grained sediments. \\
\hline & Kettle-lakes & $\begin{array}{l}\text { Water-filled hollows distributed in hummocky terrain in the westernmost alluvial fan created by the sediments } \\
\text { transported by snow and glacier-melting waters. } \\
\text { Their diameter ranges from } 2 \text { to } 20 \mathrm{~m} \text {. }\end{array}$ \\
\hline & Squeeze moraines & $\begin{array}{l}\text { Longitudinal debris ridges at the limit of the present-day glacier front. Their dimensions range from } 0.6 \text { to } 1 \mathrm{~m} \text { height and } \\
10 \text { to } 40 \mathrm{~m} \text { long. }\end{array}$ \\
\hline & Alluvial fans & $\begin{array}{l}\text { Fan-shaped deposits distributed at the foot of the mudflows generated in the moraine and in contact with the proglacial } \\
\text { outwash plains drained by the proglacial streams flowing towards the coast. }\end{array}$ \\
\hline \multirow[t]{10}{*}{ Moraine system } & Lagoons & Semi-permanent intra-moraine lakes of decametric dimensions. \\
\hline & Polished blocks & Metre-sized granodiorite and basalt rocks showing evidences of glacial polish and striae. \\
\hline & Sorted-circles & Features of centimetre size developed in gentle areas $\left(4-6^{\circ}\right)$ with fine-grained sediments. \\
\hline & Stone stripes & Features of centimetre size developed in gently slopes $\left(8-12^{\circ}\right)$ with fine-grained sediments. \\
\hline & Solifluction landforms & $\begin{array}{l}\text { Generalized solifluction processes mobilizing the moraine sediments intensely affected by frost shattering. } \\
\text { Some lobe morphologies were observed in the northern slope }(0.5 \mathrm{~m} \text { height, } 1-3 \mathrm{~m} \text { long). }\end{array}$ \\
\hline & Slumps & $\begin{array}{l}\text { In the upper part different generations of scars are observed, the most recent ones leaving permafrost exposed at the } \\
\text { surface. Rapid mass movements (mudflows) in fine-grained sediments transport material down-valleys. The sliding } \\
\text { surface corresponds to the limit of the active layer in contact with the permafrost table (between } 0.5 \text { and } 1.2 \mathrm{~m} \text { depth). } \\
\text { More abundant on the northern slope of the moraine. Highly variably size, from some metres to hundreds of metres. }\end{array}$ \\
\hline & Frost mounds & Pyramidal features (1-1.5 m height, $1 \mathrm{~m}$ long) distributed mainly in the north slope of the moraine. \\
\hline & Pronival ramparts & Debris accumulation at the foot of long-lying snow patches forming longitudinal ridges (1.5-2 m height, $50-100 \mathrm{~m}$ long). \\
\hline & Lakes & $\begin{array}{l}\text { Water bodies distributed between the moraine and the bedrock outcrops. One of the lakes has no outflow (endorheic lake, } \\
40 \times 30 \mathrm{~m}) \text {, while from the other }(100 \times 30 \mathrm{~m}) \text { flows a stream towards a coastal lagoon forming an alluvial fan in its } \\
\text { mouth. }\end{array}$ \\
\hline & Landslides & $\begin{array}{l}\text { Erosive scars and convex accumulations of debris located on the slopes of the moraine ( } 50-20 \mathrm{~m} \text { long, } 25-15 \mathrm{~m} \text { wide). The } \\
\text { three landslides are shallow and triggered by water saturation of the active layer of permafrost. }\end{array}$ \\
\hline \multirow[t]{7}{*}{ Bedrock plateaus } & Talus cones & Accumulation of coarse sediments at the foot of the cliffs. Poorly lichenized surfaces, suggesting active dynamics. \\
\hline & Rockfalls & Accumulations of large blocks fallen from the outcrops in the margins of the basalt plateaus. \\
\hline & Earth hummocks & Dome-shaped vegetated features located in relatively flat areas near bird colonies, where organic-rich soils are present. \\
\hline & Solifluction landforms & Lobe-shaped landforms in gentle slopes $\left(4-6^{\circ}\right)$ near bird colonies with a dense vegetation cover. \\
\hline & Stone sorted-circles & Features of centimetre size developed in gentle areas $\left(6-8^{\circ}\right)$ without vegetation cover and fine-grained sediments. \\
\hline & Stone stripes & Features of centimetre size developed in gentle slopes $\left(8-12^{\circ}\right)$ without vegetation cover and fine-grained sediments. \\
\hline & Polished surfaces & Basalt blocks and bedrock surfaces showing traces of glacial polish and scratches. \\
\hline \multirow{9}{*}{$\begin{array}{l}\text { Marine terraces and } \\
\text { present-day beach }\end{array}$} & Present-day beach & Distributed in the contours of the peninsula and intensely used by the wildlife. \\
\hline & Marine terraces & See Table 2. \\
\hline & Tombolos & $\begin{array}{l}\text { The accumulation of sediments between the beach and offshore rock outcrops has generated several tombolos of } \\
\text { decametric size in the southern beaches. }\end{array}$ \\
\hline & Lagoons & $\begin{array}{l}\text { Several lagoons are distributed in the flat areas present between the raised beaches. In the main bay these lagoons are } \\
\text { semi-permanent water bodies, whereas in the western side the large lagoon is permanent ( } 180 \mathrm{~m} \text { long, } 90 \mathrm{~m} \text { wide). }\end{array}$ \\
\hline & Alluvial fans & $\begin{array}{l}\text { Fan-shaped deposits of decametric dimensions built up from the moraine material, basically through debris flows and } \\
\text { sediments transported by snow-melting streams. In the western margin two alluvial fans entered the lagoon, while in the } \\
\text { main bay the upper marine terraces have been eroded by a higher-energy alluvial fan constituted by coarser sediments. }\end{array}$ \\
\hline & Mudboils & $\begin{array}{l}\text { Relatively circular landforms }(\varnothing<1 \mathrm{~m}) \text { constituted by a matrix of silty sediments with some gravels in the middle ejected } \\
\text { by frost heave. Abundant in T3. }\end{array}$ \\
\hline & Penguin mounds & $\begin{array}{l}\text { Accumulation of penguin guano forming dome-shaped mounds ( } 1 \mathrm{~m} \text { height, } 5 \mathrm{~m} \text { long). Distributed in marine terraces T2, } \\
\text { T3, T4 and T5. }\end{array}$ \\
\hline & Elephant seal scars & $\begin{array}{l}\text { The displacement of elephant seals generates parallel scars and grooves ( } 40-90 \mathrm{~m} \text { long, 1-1.5 m wide) distributed } \\
\text { perpendicularly to the marine terraces. }\end{array}$ \\
\hline & & Erosion particularly affects levels $\mathrm{T} 3$ to $\mathrm{T} 1$. \\
\hline
\end{tabular}

Antarctic Peninsula (AP) started around $14 \mathrm{ka}$ BP and stabilized around 6 ka BP (Ingólfsson et al., 1998, 2003). In the case of the South Shetland Islands, a similar chronology was reported for Barton Peninsula, where cosmogenic dating suggested that the thinning of the Collins ice cap started around $15.5 \mathrm{ka}$ BP (Seong et al., 2009). In the nearby Byers Peninsula the eastwards retreat of Rotch Dome glacier started during the Early Holocene in the western part of this peninsula (Toro et al., 2013), continued through the Mid Holocene in the central plateau and extended to the eastern part during the Late Holocene (Oliva et al., 2014). Following the retreat pattern of Rotch Dome observed in Byers Peninsula, it is likely that the deglaciation of Elephant Point has occurred through the Holocene.

The existence of white granodiorite blocks in the moraine may be indicative of a former over-riding glaciation in the area. These rocks do not outcrop in the western half of Livingston Island, therefore, they must have been transported from farther east in the SSI or from the AP region (Hall and Perry, 2004). They may correspond to ice rafted detritus transported to Livingston Island during the Last Glaciation, when the ice cap covering both the SSI and the AP region were more extensive (Bentley et al., 2006). The granodiorite boulders would have been brought from the AP by icebergs to the SSI. Subsequent to their initial deposition, these blocks were reworked by the local glacier dynamics in the area.

Following the last deglaciation, the southern bay was the first icefree environment in Elephant Point. The existence of several raised marine beaches suggests that the deglaciation process must have started several millennia ago, allowing the glacioisostatic rebound to generate these marine terraces. This complete sequence of Holocene marine terraces has been identified widely across the SSI (Bentley et al., 2005; López-Martínez et al., 2012). Geochronological studies in several other enclaves of the SSI based on coastal lagoon sediments or radiometric dating of whale bones suggest that the formation of the highest levels in this archipelago correspond to the Early-Mid Holocene, while the raised beaches emplaced at lower elevations developed during the Late Holocene (Fretwell et al., 2010; Watcham et al., 2011). In Byers Peninsula, datings of whale bones included in several marine terraces at elevations up to $10 \mathrm{~m}$ a.s.l. reported ages in all cases constrained to the Late Holocene. The samples from the raised beaches below $6 \mathrm{~m}$ a.s.l. result in ages younger than $500 \mathrm{yr}$. cal BP (Hall and Perry, 2004), the terrace at $7.6 \mathrm{~m}$ a.s.l. provided $1.2 \mathrm{ky}$ cal BP (Curl, 1980) 
Table 2

Elevation, slope angle and main characteristics of the five levels of marine terraces distributed in Elephant Point.

\begin{tabular}{|c|c|c|c|}
\hline Terrace & Elevation $(\mathrm{m})$ & Riser, slope angle $\left({ }^{\circ}\right)$ & Characteristics \\
\hline T1 & 10 & 20 & $\begin{array}{l}\text { Presence of a colony of elephant seals. } \\
\text { Dense vegetation cover. }\end{array}$ \\
\hline $\mathrm{T} 2$ & 7 & 18 & Appears only in the westernmost part of the main bay. Highly eroded by the action of elephant seals (haul scars). \\
\hline T3 & 5 & 10 & $\begin{array}{l}\text { Characterized by intense cryoturbation processes, namely the formation of mudboils and small sorted-circles. } \\
\text { A semi-permanent lagoon is distributed on it. }\end{array}$ \\
\hline T4 & 3 & 6 & Vast flat terrace with significant biological activity. \\
\hline T5 & 2 & 4 & Abundant wildlife (penguins, sea lions, elephant seals) and remains of dead animals. \\
\hline
\end{tabular}

and the upper level at 9-10 m a.s.l. reported $1.8 \mathrm{ky}$ cal BP (Hansom, 1979; Hall and Perry, 2004). Therefore, using these ages the average rates of isostatic uplift for the Late Holocene can be estimated at about $0.6-1.2 \mathrm{~cm} / \mathrm{ky}$. It seems reasonable to consider a similar age for the formation of the marine terraces at the nearby Elephant Point taking into account that the Holocene isostatic uplift in both sites has been quantified at 10-14 m (Fretwell et al., 2010; Watcham et al., 2011). If we assume that T1, the highest marine terrace in Elephant Point located at 10 a.s.l., corresponds to the same level than in Byers Peninsula, a maximum age of $1.8 \mathrm{ky}$ cal BP can be inferred for the formation of the moraine overlying the terrace $\mathrm{T} 1$ in Elephant Point. Indeed, we can deduce that the vast area extending across the raised beaches T3-T5 has probably emerged only over the last $500 \mathrm{yr}$. cal BP, when the relative sea level fall has possibly accelerated in the SSI (Watcham et al., 2011).

The degree of soil development and patterned ground evolution in the different marine terraces provides also relative chronological information about the age of their formation. In Byers Peninsula Navas et al. (2005) detected very distinctive levels of edaphic development in the cryogenic soils of the different terraces. In Elephant Point, the degree of development of the patterned ground in the oldest terraces is indicative of a significantly older age than the lowest ones, where it is absent. According to the existing ages for marine terraces in Byers Peninsula, the pattern ground landforms occurring in T1 and T2 must have formed during the last two millennia, while patterned ground and mudboils present in T3 must have developed during the last 500 years. The presence of patterned ground on Holocene raised beaches has been also observed in other ice-free environments in this archipelago at elevations ranging from 13 to $20 \mathrm{~m}$ a.s.l., always being connected to the active layer, hence indicating permafrost conditions (López-Martínez et al., 2012). The patterned ground landforms distributed in the bedrock plateaus near the coast in Elephant Point show a similar degree of development, suggesting that these environments probably also remained icefree at a similar stage than when the uppermost terraces emerged.

The relief in this peninsula is largely controlled by the frontal moraine system created by the retreat of Rotch Dome glacier upslope. The significant height of the moraine, including several arches distributed in between the highest moraine crests, suggests that its formation must be a consequence of different retreating and advancing pulses, with several prolonged phases of stabilization during the long-term Holocene retreat. In the highest outermost ridge of the moraine at an altitude of 42 and $44 \mathrm{~m}$ a.s.l. well-rounded cobbles and bone whales were observed. They are interpreted as being part of a Pleistocene marine terrace that was subsequently reworked by a glacier readvance. The age of the deposition of whale bones could be inferred by $\mathrm{C}^{14}$ dating, though it would provide an age of a period of glacier shrinking during the Pleistocene with formation of raised beaches, not the date of formation of the moraine. Subsequently to their deposition, the bulldozing effect of the glacier incorporated these marine sediments which are now exposed at the surface. Similar deposits have been observed in other moraine deposits in the SSI, hence, the formation of the highest beaches in this archipelago is attributed to previous interglacial periods considering that the upper Holocene marine limit is located at an altitude of 20$22 \mathrm{~m}$ a.s.l. (Hall, 2003; Fretwell et al., 2010; Watcham et al., 2011).

Regarding the chronology of development of the moraine, the (maximum) age of $1.8 \mathrm{ky}$ cal BP for the deposition of the sediments of the southern slope could be complemented with the cosmogenic dating of polished blocks with glacial striae traces present in the internal moraine ridge. This would be indicative of the age of stabilization of the inner moraine, which would help to constrain the age of development of the whole moraine system.

\subsection{Present-day geomorphological processes and frozen ground conditions}

Despite the recent slowdown in the loss of glacier mass in Livingston Island, its declining trend over the past decades has been very significant (Navarro et al., 2013). The rapid retreat of Rotch Dome between 1956 and 2010 has exposed $17.3 \%$ of the total ice-free spatial coverage in this peninsula in parallel to the pronounced warming recorded in the AP region (Turner et al., 2005; Steig et al., 2009). Immediately after the deglaciation these newly ice-free environments are subjected to intense sediment reworking and redistribution characteristic of the paraglacial stage (Ballantyne, 2002).

The moraine area is affected by very active and intense geomorphological dynamics, with a variety and broad spatial distribution of
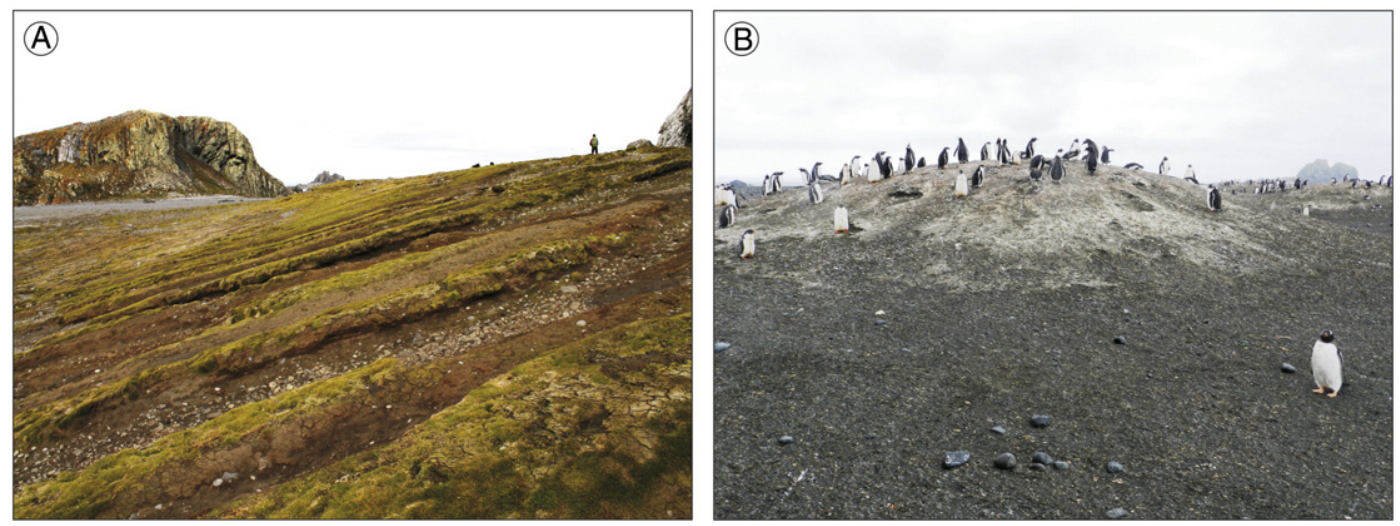

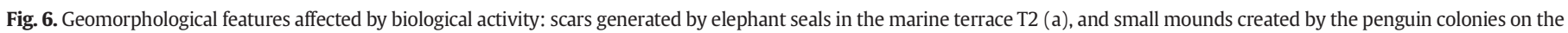
marine terraces (b). 
Table 3

Depth of the thawed soil layer in each transect in late January 2014.

\begin{tabular}{lllll}
\hline Transects & Sites & Depth $(\mathrm{cm})$ & & Minimum \\
\cline { 3 - 5 } & & Average & Maximum & 25 \\
\hline Transect 1 & 20 & 55.9 & 92 & 45 \\
Transect 2 & 13 & 65.3 & 95 & 22 \\
Transect 3 & 16 & 47.4 & 82 & 22 \\
Total & 49 & 57.5 & 95 & \\
\hline
\end{tabular}

periglacial landforms: frost shattering is especially effective on unconsolidated glacial debris, cryoturbation processes have generated small-scale patterned ground phenomena in gentle areas and slow and fast mass wasting movements transfer the sediments downslope. Slope processes are widespread on the northern side of the moraine and less abundant in the southern exposed slope, where snow patches remain longer and have favoured the development of pronival ramparts. The structure of the pronival ramparts is similar to that described in other areas (Ballantyne, 1987; Shakesby, 1997; Hedding and Sumner, 2013), with arcuate ridges and basal talus at their foot. Frost mounds are distributed on the ice-rich permafrost terrain of the moraine; although not found in an ice-core moraine, frost mounds may include up to $80 \%$ of ice content as observed in other permafrost environments (Fortier et al., 2008).

Mudflow dynamics is very intense especially during periods with fairly positive temperatures and rainy events. Therefore, it is enhanced during the summer season, when $80 \%$ of the days recorded precipitation events in Livingston Island, mostly in the form of liquid precipitation (Bañón et al., 2013). Positive temperatures favour snow and ice-melting together with the thawing of the most surficial layers, which favours mass wasting processes. In January-February 2014 the maximum air temperatures were highly positive, as shown by the maximum values of 6-6.5 ${ }^{\circ} \mathrm{C}$ recorded in the nearby Byers Peninsula; from January to December 2014, positive air temperatures were recorded during 19 days (Oliva et al., submitted for publication). Solifluction processes are widespread on the moraine, though with minor landforms associated. The movement of the unconsolidated sediments on the moraine disturbs vegetation development (Eichel et al., 2015).

The landscape in moraine environments in other areas in Maritime Antarctica shows a similar distribution of the processes and landforms existing in Elephant Point (Guglielmin et al., 2008; López-Martínez et al., 2012). Runoff triggers increased erosion on these unconsolidated sediments, mobilizing them towards the proglacial outwash plains. Here, in the western side of this peninsula, thermokarst features have been observed in the form of tens of kettle-lakes at 5-10 $\mathrm{m}$ a.s.l. spread over this recently glaciated terrain. Thermokarst processes in this area are probably associated with the thawing of permafrost, not related to glacial abrasion since no glacial ice remnants were observed across this flat area. The presence of ice-rich permafrost in the moraine (Fig. 8 ) suggests that the proglacial area is very likely to be also characterized by permafrost. The fact that the moraine does not correspond to an icecored moraine is also indicative that the depressions existing in the upper part of the moraine are also related to permafrost thawing of the ice-rich permafrost. Thermokarst landforms in the SSI have been associated with the degradation of the local permafrost conditions at elevations below ca. $20 \mathrm{~m}$ a.s.l. (Serrano et al., 2008; Vieira et al., 2010; Bockheim et al., 2013).

In Elephant Point the measurements conducted with a probe reported a widespread distribution of the frozen ground in this peninsula. Due to the cold and snowy conditions of the preceding months there can be no assurance that the thawed layer corresponded to the depth of the active layer or to seasonal frost. In the nearby Byers Peninsula the thickness of the active layer ranges between 0.9 and $1.5 \mathrm{~m}$ (de Pablo et al., 2013, 2014; Oliva et al., submitted for publication), slightly higher than the thawed layers at the time of this research. As permafrost was observed almost down to sea level in the scars generated by mudflow in the moraine, it is likely to think that permafrost occupies a broad spatial extent today in Elephant Point controlling the periglacial activity and terrestrial ecosystem dynamics. This is in line with other studies on ground ice distribution in the Maritime Antarctic, stating that it
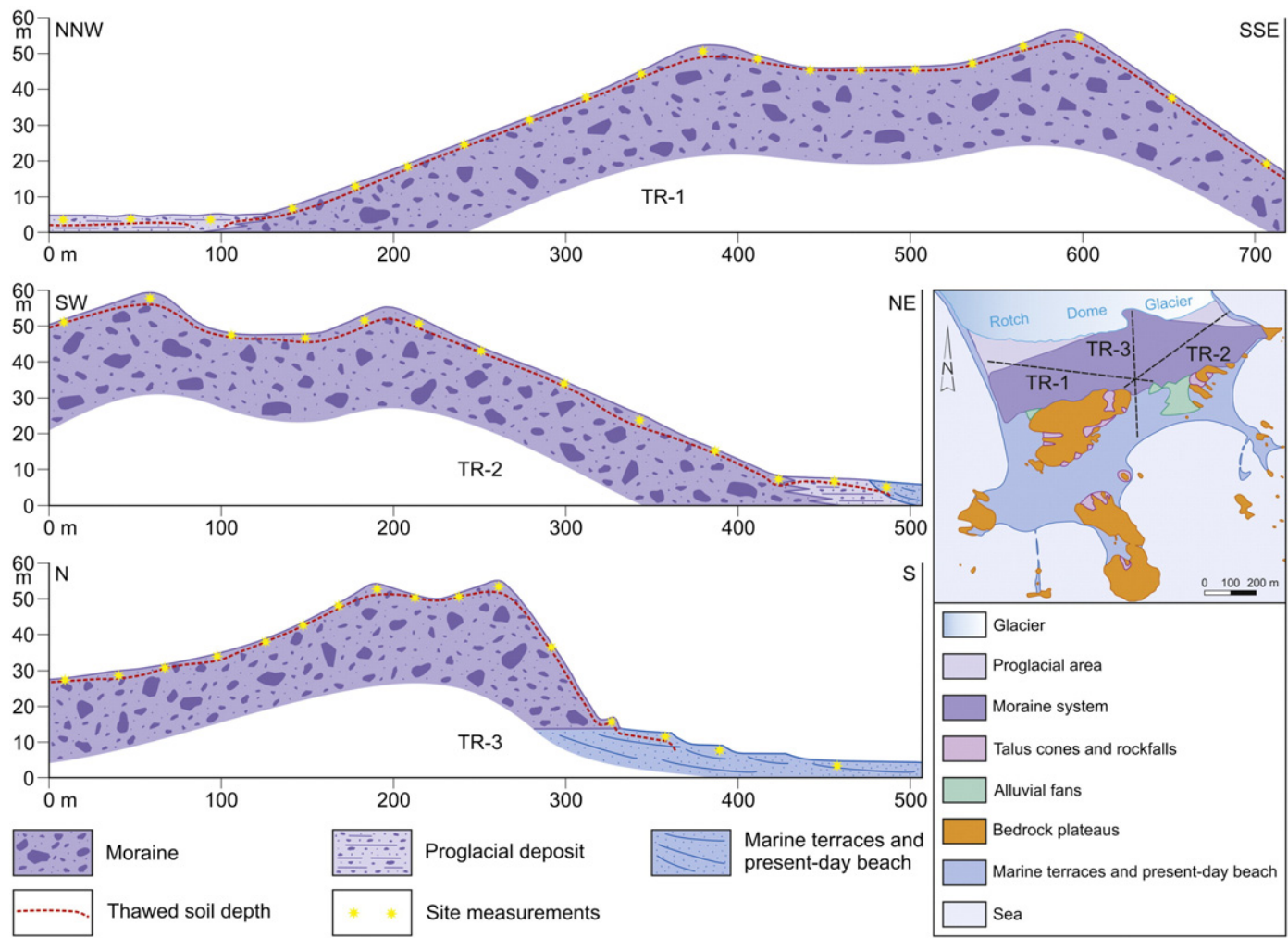

Fig. 7. Geomorphological sketches with the depths of the thawed layer at late January 2014 along the three transects (TR). 

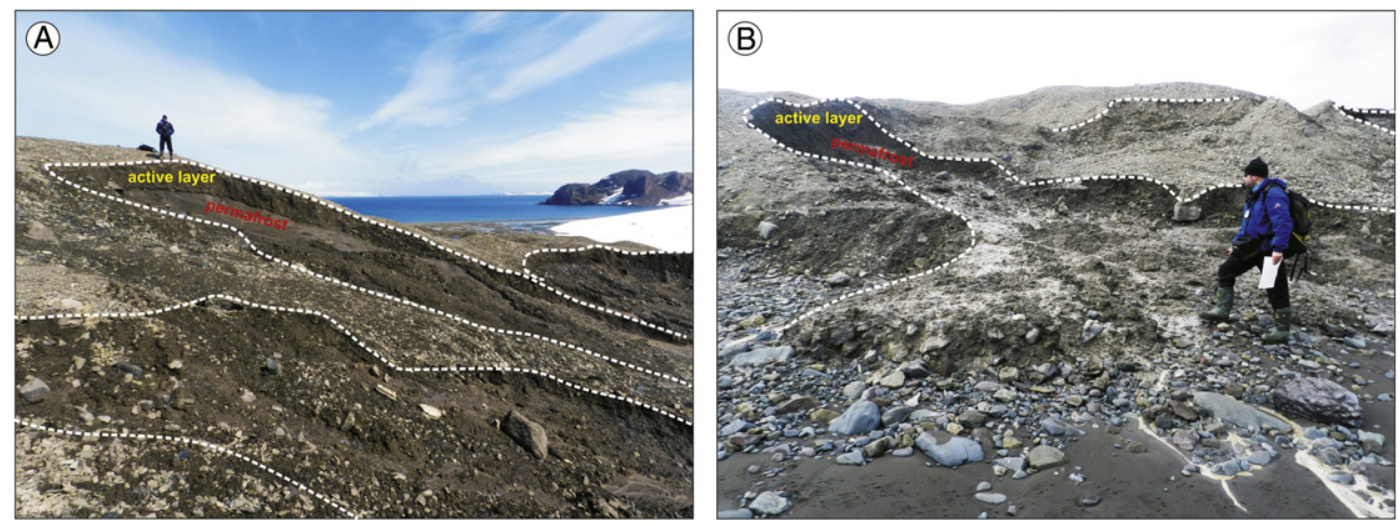

Fig. 8. Slumps on the moraine sediments: in the northwestern slope of the moraine (a), and along the coastline (b).

exists near sea level in the form of rock glaciers, pronival lobes, ice wedges and ice-cored moraines (Bockheim and Hall, 2002; Serrano and López-Martínez, 2000; Serrano et al., 2008; Bockheim et al., 2013). In Elephant Point the only area without permafrost conditions may be the lowest marine terraces, where no frozen layer was detected in two sites.

The age of permafrost in recently deglaciated areas is strongly related to the thermal character of the base of the glaciers. The fact of being cold-based or warm-based glaciers is crucial to infer the age of permafrost. However, no data exists on this aspect for Rotch Dome glacier in Elephant Point or in Byers Peninsula. In Hurd Peninsula, in the central part of Livingston Island, the glacier ice cap has been defined as a polythermal ice mass with a relatively higher proportion of warmbased surfaces (Navarro et al., 2013). Permafrost may form immediately after the deglaciation in a warm-based glacier environment; hence, in this situation permafrost would be of Holocene age in Elephant Point. By contrast, in the case of a cold-based glacier permafrost existed beneath the glacier before the deglaciation, thus it would be of Pleistocene-Holocene age.

\subsection{Biological activity and early-human traces in the lowest marine terraces}

The lowest areas are intensely affected by the local fauna, namely elephant seals and penguin rookeries, which can generate significant impacts on the geomorphological features distributed near the shoreline (Fig. 6). The abandoned penguin mounds are observed all across the SSI and have been examined to understand the initial occupation of the penguin colonies and their former distribution in this archipelago (Emslie, 1995; Sun et al., 2000). Indeed, radiocarbon datings of these penguin mounds have been used to infer minimum ages for the development of the marine terraces where they are distributed, although they showed very different ages for levels of marine terraces placed at similar altitudes in the different islands, ranging from the Mid to the Late Holocene (del Valle et al., 2002; Emslie et al., 2011).

In the two lowermost terraces, there are traces of early-human occupation in Maritime Antarctica in rock shelters next to outcrops with whale vertebrae and ribs distributed in the floor. Livingston is one of the areas in the SSI where archaeological research on sealer camps has been rather fruitful (Zarankin et al., 2011). In Byers Peninsula more than twenty human-built sites of a surface ranging from 15 to $20 \mathrm{~m}^{2}$ were identified at natural shelters, such as a cave or open air rock formations (Zarankin and Senatore, 2005). According to the archaeologist Zarankin (pers. communication) it is likely that the archaeological sites in Elephant Point were built during similar stages as those of Byers, corresponding probably to the three major periods of seal hunting activity in the SSI: 1820s, 1840 s and 1870 s.

\section{Conclusions}

Elephant Point is a small recently deglaciated environment of $1.16 \mathrm{~km}^{2}$ distributed in the SW corner of Livingston Island. In this paper we introduce a detailed geomorphological surveying conducted in the field during the Antarctic campaign in January 2014. The geomorphological dynamics in Elephant Point is similar to that occurring in other ice-free environments in the SSI, with very active and widespread periglacial processes. Despite its reduced size, this peninsula shows a very rich range of periglacial landforms. Four different geomorphological units have been identified in the periglacial landscape in this peninsula: proglacial area, moraine system, bedrock plateaus and marine terraces.

The warmer climate conditions recorded during the Late Pleistocene and Early Holocene in the AP region conditioned the progressive retreat of Rotch Dome. This trend has been accentuated over the past half century, when $17.3 \%$ of this peninsula became ice-free. The long-term Holocene glacier shrinking was also accompanied by some periods of glacier regrowth, which generated the formation of an extensive moraine complex ( 25 to $55 \mathrm{~m}$ height) with several arches. As the lowest coastal areas became ice-free, glacio-isostatic rebound favoured the development of a sequence of five different marine terraces. The highest marine terrace lies in contact with the southern slope of the moraine system, which allows to infer a minimum age for the formation of the moraine. Taking into account the chronology of formation of marine terraces in the nearby Byers Peninsula, a maximum age of $1.8 \mathrm{ky}$ cal $\mathrm{BP}$ is inferred for the initial development of the present-day moraine complex at Elephant Point. Nowadays, the moraine is affected by very active geomorphic processes. Cryoturbation and mass wasting processes are very intensely reworking the unconsolidated sediments and thermokarst features have also developed in the most recently deglaciated areas of flat topography.

This geomorphological framework should be complemented in the future with geochronological studies to establish the timing of the deglaciation in the area. Several sedimentary records (lake sediments, raised beaches, moraine) could be examined for that purpose in Elephant Point, with the use of different dating techniques. Inferring the age of formation of the moraine in Elephant Point would be of special interest for the entire Livingston Island, since this moraine system is also found in Byers and no data exists about its age.

On the other hand, in situ measurements of the depth of the thawed layer at late January 2014 showed a wide distribution of the frozen ground in Elephant Point. The nature of these frozen conditions is probably related to a permafrost regime in most of the peninsula, since visual observations of permafrost were made almost down to sea level in scars generated by mudflows in the moraine sediments.

Interestingly, minor geomorphological units near the shoreline were created by the biological activity of penguin colonies (penguin mounds) 
and others landforms were affected by the erosion generated by elephant seals (haul scars). Early human occupation was also deduced from archaeological sites built in natural shelters.

Supplementary data to this article can be found online at http://dx. doi.org/10.1016/j.geomorph.2016.01.020.

\section{Acknowledgments}

This work was supported by the research project HOLOANTAR (Holocene environmental change in the Maritime Antarctic Interactions between permafrost and the lacustrine environment) and the Portuguese Polar Programme (PROPOLAR), both funded by the Portuguese Science Foundation. Special thanks also to the invaluable support in the field of the Brazilian and Chilean Antarctic Programmes. The first author thanks the AXA Research Fund for funding his research activities. We are grateful to Prof Dr. Gonçalo Viera (University of Lisbon) for his support during the preparation of the field work and valuable comments on the elaboration of this paper. We also acknowledge Mike Bentley (Durham University) for comments on an early draught of this paper.

\section{References}

Abram, N.J., Mulvaney, R., Wolff, E.W., Triest, J., Kipfstuhl, S., Trusel, L.D., Vimeux, F., Fleet, L., Arrowsmith, C., 2013. Acceleration of snow melt in an Antarctic Peninsula ice core during the twentieth century. Nat. Geosci. 6, 404-411.

Balco, G., Schaefer, J.M., LARISSA group, 2013. Exposure-age record of Holocene ice sheet and ice shelf change in the northeast Antarctic Peninsula. Quat. Sci. Rev. 59, 101-111.

Ballantyne, C.K., 1987. Some observations on the morphology and sedimentology of two active protalus ramparts, Lyngen, Northern Norway. Arct. Alp. Res. 19, 167-174.

Ballantyne, C.K., 2002. Paraglacial geomorphology. Quat. Sci. Rev. 21, 1935-2017.

Bañón, M., Justel, A., Velázquez, D., Quesada, A., 2013. Regional weather survey on Byers Peninsula, Livingston Island, South Shetland Islands, Antarctica. Antarct. Sci. 25, 146-156.

Benn, D., Evans, D., 2010. Glaciers and Glaciation. second ed. Hodder Arnold.

Bentley, M.J., Hodgson, D.A., Smith, J.A., Cox, N.J., 2005. Relative sea level curves for the South Shetland Islands and Marguerite Bay, Antarctic Peninsula. Quat. Sci. Rev. 24, 1203-1216.

Bentley, M.J., Fogwill, C.J., Kubik, P.W., Sugden, D.E., 2006. Geomorphological evidence and cosmogenic 10Be/26A1 exposure ages for the last glacial maximum and deglaciation of the Antarctic Peninsula ice sheet. Geol. Soc. Am. Bull. 118, 1149-1159.

Bentley, M.J., Hodgson, D.A., Smith, J.A., Ó Cofaigh, C., Domack, E.W., Larter, R.D., Roberts, S.J., Brachfeld, S., Leventer, A., Hjort, C., Hillenbrand, C.D., Evans, J., 2009. Mechanisms of Holocene paleoenvironmental change in the Antarctic Peninsula region. The Holocene 19, 51-69.

Bentley, M.J., Johnson, J.S., Hodgson, D.A., Dunai, T., Freeman, S.P., Ó Cofaigh, C., 2011. Rapid deglaciation of Marguerite Bay, Western Antarctic Peninsula in the Early Holocene. Quat. Sci. Rev. 30, 3338-3349.

Björck, S., Hakansson, H., Zale, R., Karlen, W., Jönsson, B.L., 1991. A Late Holocene lake sediment sequence from Livingston Island, South Shetland Islands, with palaeoclimatic implications. Antarct. Sci. 3, 61-72.

Björck, S., Hjort, C., Ingólfsson, O., Zale, R., Ising, J., 1996. Holocene deglaciation chronology from lake sediments. BAS Geomap Series. Sheet 5-A. British Antarctic Survey, Cambridge, UK, pp. 49-51.

Bockheim, J., Hall, K.J., 2002. Permafrost, active-layer dynamics and periglacial environments of continental Antarctica. S. Afr. J. Sci. 98, 82-90.

Bockheim, J., Vieira, G., Ramos, M., López-Martínez, J., Serrano, E., Guglielmin, M., Wilhelm, K., Nieuwendam, A., 2013. Climate warming and permafrost dynamics in the Antarctic Peninsula region. Glob. Planet. Chang. 100, 215-223.

Calvet, J., García-Sellés, D., Corbera, J., 1999. Fluctuaciones de la extensión del casquete glacial de la Isla Livingston (Shetland del Sur) desde 1956 hasta 1996. Acta Geol. Hisp. 34, 365-374.

Cary, S.C., McDonald, I.R., Barrett, J.E., Cowan, D.A., 2010. On the rocks: the microbiology of Antarctic Dry Valley soils. Nat. Rev. Microbiol. 8 (2), 129-138.

Curl, J.E., 1980. A glacial history of the South Shetland Islands, Antarctica. Inst. Polar Stud. Rep. 63 (129 pp.).

De Pablo, M.A., Blanco, J.J., Molina, A., Ramos, M., Quesada, A., Vieira, G., 2013. Interannual active layer variability at the Limnopolar Lake CALM site on Byers Peninsula, Livingston Island, Antarctica. Antarct. Sci. 25, 167-180.

De Pablo, M.A., Ramos, M., Molina, A., 2014. Thermal characterization of the active layer at the limnopolar Lake CALM-S site on byers peninsula (Livingston Island), Antarctica. Solid Earth 5, 721-739.

del Valle, R.A., Montalti, D., Inbar, M., 2002. Mid-Holocene macrofossil-bearing raised marine beaches at Potter Peninsula, King George Island, South Shetland Islands. Antarct. Sci. 14, 263-269.

Eichel, J., Corenblit, D., Dikau, R., 2015. Conditions for feedbacks between geomorphic and vegetation dynamics on lateral moraine slopes: a biogeomorphic feedback window. Earth Surf. Process. Landf. http://dx.doi.org/10.1002/esp.3859.

Emslie, S.D., 1995. Age and taphonomy of abandoned penguin rockeries in the Antarctic Peninsula Region. Polar Rec. 31, 409-418.
Emslie, S.D., Baumann, K., van Tuinen, M., 2011. Late Holocene occupation of Gentoo penguins Pygoscelis papua on Byers Peninsula, Livingston Island, Antarctica. Polar Biol. 34 (2), 283-290.

Evans, D.J.A., 2007. Moraine forms and genesis. In: Elias, S.A. (Ed.), Encyclopedia of Quaternary Science. Elsevier, Oxford, pp. 772-784.

Fortier, R., LeBlanc, A.M., Allard, M., Buteau, S., Calmels, F., 2008. Internal structure and conditions of permafrost mounds at Umiujaq in Nunavik, Canada, inferred from field investigation and electrical resistivity tomography. Can. J. Earth Sci. 45, 367-387.

Fretwell, P.T., Hodgson, D.A., Watcham, E.P., Bentley, M.J., Roberts, S.J., 2010. Holocene isostatic uplift of the South Shetland Islands, Antarctic Peninsula, modelled from raised beaches. Quat. Sci. Rev. 29, 1880-1893.

Guglielmin, M., Boschi, D., D'Agata, C., Ellis-Evans, C., Worland, M.R., 2008. Periglacial and permafrost map of Signy Island, South Orkneys Islands, Maritime Antarctica. In: Kane D.L., Hinkel, K.M. (Eds.), Proceedings of 9th International Conference on Permafrost 1. University of Alaska Fairbanks, Alaska, USA, pp. 569-574.

Hall, B.L., 2003. An overview of Late Pleistocene glaciation in the South Shetland Islands, Antarctic Peninsula climate variability. Antarct. Res. Ser. 79, 103-113.

Hall, B.L., Perry, E.R., 2004. Variations in ice rafted detritus on beaches in the South Shetland Islands: a possible climate proxy. Antarct. Sci. 16, 339-344.

Hall, B.L., Koffman, T., Denton, G.H., 2010. Reduced ice extent on the Western Antarctic Peninsula at 700-970 cal. yr B.P. Geology 38, 635-638.

Hansom, J.D., 1979. Radiocarbon dating of a raised beach at $10 \mathrm{~m}$ in the South Shetland Islands, Antarctica. Mar. Geol. 53, 211-229.

Hedding, D.W., Sumner, P.D., 2013. Diagnostic criteria for pronival ramparts: site morphological and sedimentological characteristics. Geogr. Ann. A 95, 315-322.

Ingólfsson, O., Hjort, C., Berkman, P.A., Björck, S., Colhoun, E., Goodwin, I.D., Hall, B.L. Hirakawa, K., Melles, M., Prentice, M.L., 1998. Antarctic glacial history since the Last Glacial maximum: an overview of the record on land. Antarct. Sci. 10 (3), 326-344.

Ingólfsson, O., Hjort, C., Humlun, O., 2003. Glacial and climate history of the Antarctic Peninsula since the last glacial maximum. Arct. Antarct. Alp. Res. 35 (2), 175-186.

Joly, F., 1997. Glossaire de géomorphologie. Base de données sémiologiques Pour La Cartographie. Armand Colin, Paris (325 pp.).

López-Martínez, J., Serrano, E., 2002. Geomorphology of Deception Island. In: LópezMartínez, J., Smellie, J.L., Thomson, J.W., Thomson, M.R.A. (Eds.), Geology and Geomorphology of Deception Island. BAS Geomap Series. Sheet 6-A and 6-B. British Antarctic Survey, Cambridge, UK.

López-Martínez, J., Martínez de Pisón, E., Serrano, E., Arche, A., 1996. Geomorphological map of Byers Peninsula, Livingston Island. BAS Geomap Series. Sheet 5-A. British Antarctic Survey, Cambridge, UK.

López-Martínez, J., Serrano, E., Schmid, T., Mink, S., Linés, C., 2012. Periglacial processes and landforms in the South Shetland Islands (Northern Antarctic Peninsula region). Geomorphology 155, 62-79.

Molina, C., Navarro, F.J., Calver, J., García-Sellés, D., Lapazaran, J.J., 2007. Hurd peninsula glaciers, Livingston Island, Antarctica, as indicators of regional warming: ice-volume changes during the period 1956-2000. Ann. Glaciol. 46, 43-49.

Mulvaney, R., Abram, N.J., Gagan, M.K., Hindmarsh, R.C.A., Arrowsmith, C., Fleet, L., Triest J., Sime, L.C., Alemaney, O., Foord, S., 2012. Recent Antarctic Peninsula warming relative to Holocene climate and ice-shelf history. Nature 489, 141-144.

Navarro, F., Jonsell, U., Corcuera, M.I., Martín Español, A., 2013. Decelerated mass loss of Hurd and Johnsons glaciers, Livingston Island, Antarctic Peninsula. J. Glaciol. 59 (213), 115-128.

Navas, A., Soto, J., López-Martínez, J., 2005. Radionuclides in soils of Byers Peninsula, South Shetland Islands, Western Antarctica. Appl. Radiat. Isot. 62 (5), 809-816.

Oliva, M., Antoniades, D., Giralt, S., Granados, I., Toro, M., Pla-Rabes, S., Vieira, G., 2014. La deglaciación holocena de la península byers (isla Livingston, Antártida Marítima) a partir de la datación de sedimentos lacustres. Avances de la Geomorfología en España 2012-2014, pp. 523-526.

Oliva, M., Hrbáček, F., Ruiz-Fernández, J., De Pablo, M.A., Vieira, G., Ramos, M., 2016. Active layer dynamics in three sites with contrasted topography in the Byers Peninsula (Livingston Island, Antarctica). Catena (Submitted for publication).

Osmanoglu, B., Corcuera, M.I., Navarro, F.J., Braun, M., Hock, R., 2013. Frontal ablation and temporal variations in surface velocity of Livingston Island ice cap, Antarctica. Cryosphere Discuss. 7, 4207-4240.

Pallàs, R., Casas, J.M., Smellie, J., Calvet, J., 2001. Using tephrochronology to date temperate ice: correlation between ice tephras on Livingston Island and eruptive units on Deception Island volcano (South Shetland Islands, Antarctica). The Holocene 11 (2), 149-160.

Quesada, A., Camacho, A., Lyons, W.B., 2013. Multidisciplinary research on Byers Peninsula, Livingston Island: a future benchmark for change in Maritime Antarctica. Antarct. Sci. 25 (2), 123-127.

Ramos, M., Hassler, A., Vieira, G., Hauck, C., Gruber, S., 2009. Setting up boreholes for permafrost thermal monitoring on Livingston Island in the Maritime Antarctic. Permafr. Periglac. Process. 20 (1), 57-64.

Rückamp, M., Braun, M., Suckro, S., Blindow, N., 2011. Observed glacial changes on the King George Island ice cap, Antarctica, in the last decade. Glob. Planet. Chang. 79 (1-2), 99-109.

Seong, Y.B., Owen, LA., Lim, H.S., Yoon, H.I., Kim, Y. Lee, YI, Caffee, M.W., 2009. Rate of late quaternary ice-cap thinning on King George Island, South Shetland Islands, West Antarctica defined by cosmogenic 36Cl surface exposure dating. Boreas 38, 207-213.

Serrano, E., López-Martínez, J., 1997. Geomorfología de la Península Coppermine, Isla Robert, islas Shetland del Sur, Antártida. Ser. Cient. INACH 47, 19-29.

Serrano, E., López-Martínez, J., 2000. Rock glaciers in the South Shetland Islands, Western Antarctica. Geomorphology 35, 145-162.

Serrano, E., López-Martínez, J., Cuchí, J.A., Durán, J.J., Mink, S., Navas, A., 2008. Permafrost in the South Shetland Islands (Maritime Antarctica): spatial distribution pattern. In: 
Kane, D.L., Hinkel, K.M. (Eds.), Proceedings of 9th International Conference on Permafrost 2. University of Alaska Fairbanks, Alaska, USA, pp. 1621-1625.

Shakesby, R.A., 1997. Pronival (protalus) ramparts: a review of forms, processes, diagnostic criteria and palaeoenvironmental implications. Prog. Phys. Geogr. 21, 394-418.

Shevenell, A.E., Ingalls, A.E., Domack, E.W., Kelly, C., 2011. Holocene Southern Ocean surface temperature variability west of the Antarctic Peninsula. Nature 470, 250-254.

Steig, E.J., Schneider, D.P., Rutherford, S.D., Mann, M.E., Comiso, J.C., Shindell, D.T., 2009 Warming of the Antarctic ice-sheet surface since the 1957 IGY. Nature 457, 459-462.

Steig, E.J., Ding, Q., White, J.W.C., Kuttel, M., Rupper, S.B., Neumann, T.A., Neff, P.D., Gallant, A.J.E., Mayewski, P.A., Taylor, K.C., Hoffman, G., Dixon, D., Schoenemann, S.W., Markle B.R., Fudge, T.J., Schneider, D.P., Schauer, A.J., Teel, R.P., Vaughn, B.H., Burgener, L., Williams, J., Korotkikh, E., 2013. Recent climate and ice-sheet changes in West Antarctica compared with the past 2,000 years. Nat. Geosci. 6, 372-375.

Sun, L., Xie, Z., Zhao, J., 2000. Palaeoecology: a 3,000-year record of penguin populations. Nature 407, 858.

Toro, M., Camacho, A., Rochera, C., Rico, E., Banon, M., Fernandez-Valiente, E., Marco, E. Justel, A., Avendano, M.C., Ariosa, Y., Vincent, W.F., Quesada, A., 2007. Limnological characteristics of freshwater ecosystems of Byers. Polar Biol. 30 (5), 635-649.

Toro, M., Granados, I., Pla, S., Giralt, S., Antoniades, D., Galán, L., Martínez-Cortizas, A., Soo Lim, H., Appleby, P.G., 2013. Chronostratigraphy of the sedimentary record of Limnopolar Lake, Byers Peninsula, Livingston Island, Antarctica. Antarct. Sci. 25 (2), 198-212.
Turner, J., Colwell, S.R., Marshall, G.J., Lachlan-Cope, T.A., Carleton, A.M., Jones, P.D., Lagun, V., Reid, P.A., Iagovkina, S., 2005. Antarctic climate change during last 50 years. Int. J. Climatol. 25, 279-294.

Vera, M.L., 2011. Colonization and demographic structure of Deschampsia Antarctica and Colobanthus quitensis along an altitudinal gradient on Livingston Island, South Shetland Islands, Antarctica. Polar Res. 30, 7146.

Vieira, G., Bockheim, J., Guglielmin, M., Balks, M., Abramov, A.A., Boelhouwers, J., Cannone, N., Ganzert, L., Gilichinsky, D., Goryachkin, S., López-Martínez, J., Raffi, R., Ramos, M., Schaefer, C., Serrano, E., Simas, F., Sletten, R., Wagner, D., 2010. Thermal state of permafrost and active-layer monitoring in the Antarctic: advances during the international polar year 2007-2008. Permafr. Periglac. Process. 21, 182-197.

Watcham, E.P., Bentley, M.J., Hodgson, D.A., Roberts, S.J., Fretwell, P.T., Lloyd, J.M., Larter, R.D., Whitehouse, P.L., Leng, M.J., Monien, P., Moreton, S.G., 2011. A new relative sea level curve for the South Shetland Islands, Antarctica. Quat. Sci. Rev. 30, 3152-3170.

Zarankin, A., Senatore, M.X., 2005. Archaeology in Antarctica: nineteenth-century capitalism expansion strategies. Int. J. Hist. Archaeol. 9 (1), 43-56.

Zarankin, A., Hissa, S., Salerno, M., Froner, Y.A., Radicchi, G., de Assis, L.G., Bastista, A., 2011. Paisagens em brancoarqueologia e antropologia antárticas - avanços e desafio. Vestígios Rev. Lat. Am. Arqueologia Hist. 5 (2), 9-51. 